\title{
ENTREVISTA COM OS
}

PROFESSORES CLÁUDIO

SOUTO E SOLANGE SOUTO*

Entrevistadora:

Eliane Botelho Junqueira ${ }^{1}$

\section{NOTA DO EDITOR}

Ao receber esta histórica entrevista pelas mãos do Prof. Dr. Emérito Cláudio Souto, minha reação imediata foi sugerir sua publicação, principalmente por ser um meio de homenagear a pesquisadora socióloga do direito Profa. Dra. Solange Souto e agradecer seus ensinamentos, paciência e firmeza das assertivas. A simplicidade como a professora Solange explicava os mais complexos conteúdos soava tudo simples e nos dava impressão que entendíamos a profundidade dos assuntos. O curso de sociologia do direito ministrado com Cláudio Souto no Programa de Pós-graduação em Direito da UFPE marcou a todos, não apenas por ser despedida de Cláudio e Solange dos quadros da Universidade e do ambiente de sala de aula, mas também pela alegria de termos vivenciado e compartilhado risos, conhecimentos e sugestões de leituras, de reflexões, sobre a vida pessoal e social.

Aprovada a minha hipótese por Cláudio Souto, passei às tratativas com a Profa. Dra. Eliane Junqueira, essa grande maestra da sociologia do direito nos tempos de consolidação da disciplina em solo nacional, referência a toda e qualquer pessoa quanto à pesquisa empírica sociológica do direito, real e prática. Não apenas me refiro ao retrato em preto e branco da magistratura, mas principalmente à inesquecível pesquisa sobre o ensino da sociologia jurídica no Brasil, quando realiza, junto com Luciano Oliveira, o levantamento de dados mais detalhado que se tem registro até hoje, expondo as benesses e os perigos do ensino obrigatório da sociologia do direito, consequência da Portaria 1886/94. Obrigado,

\footnotetext{
* Entrevista realizada em 1997. Nesta versão, com comentários e trechos de obras de Cláudio e Solange Souto selecionados pela entrevistadora.

${ }^{1}$ Doutora em Direito pela Universidade Federal do Rio de Janeiro, pós-doutoramento na Universidade de Wisconsin (Estados Unidos). Professora de Sociologia do Direito na Pontifícia Universidade Católica do Rio de Janeiro. Diretora do Instituto Direito e Sociedade (IDES).
} 
mãe exemplar, professora Eliane Botelho Junqueira, por admitir essa publicação. Fica a esperança e o convite para que volte a nos brindar com sua presença nos eventos da ABraSD sempre enriquecendo e provocando deslocamentos perceptivos aos debates.

\section{口n}

\section{Eliane Botelho Junqueira - A Solange estava me contando que o senhor foi registrado em Garanhuns, mas que, na verdade, o senhor é do Recife, que seu pai era político, deputado...}

Cláudio Souto - Vamos dizer que não pude nascer em Garanhuns por causa de problemas da Revolução de 30, pois sou de 1931. Mas como meu pai muito

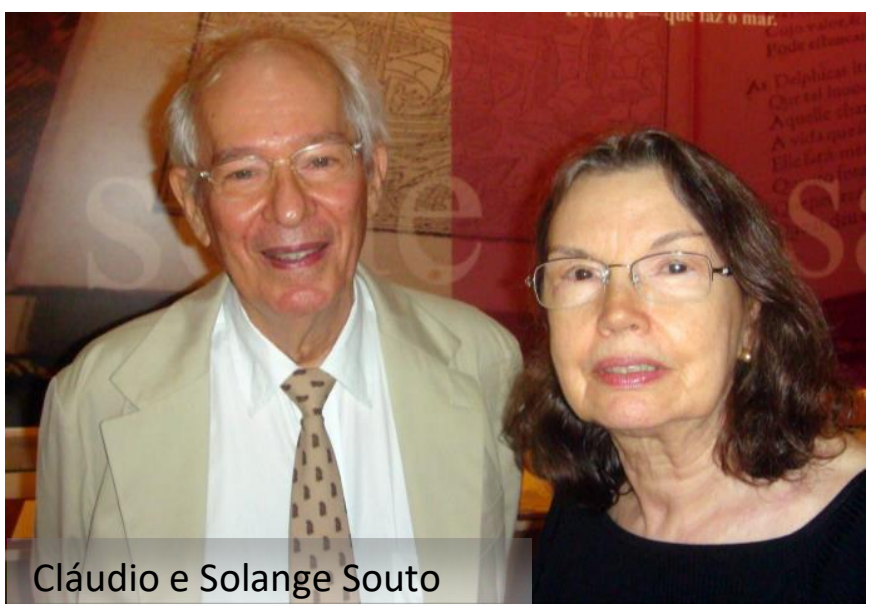
desejava, registrou-me como se eu tivesse nascido em Garanhuns... Oficialmente, eu sou natural de Garanhuns.

EBJ - E seu pai era político, deputado.

CS - Ele era deputado federal. Chamava-se Antônio da Silva Souto Filho.

Solange Souto - Naquele tempo já havia senador?

CS - Ele foi senador estadual, federal não. Ele morreu com 51 anos.

EBJ - Bastante jovem. E ele tinha formação em direito?

CS - Tinha formação em direito. Ele era curador de órfãos. Não sei se corresponde hoje a juiz de órfãos, acho que é juiz de órfãos, mas naquela época chamava-se curador de órfãos.

\section{EBJ - E como foi a decisão de fazer a faculdade de direito?}

CS - A decisão foi normal... naquela época havia direito, engenharia e medicina... Quem não gostava de engenharia, quem não gostava de medicina, ia fazer direito. Mas quando fiz o curso de direito, lá pelo quinto ano, e quando recém-formado, tive até vontade de estudar medicina porque estava decepcionado com o teor científico das faculdades de direito. Pensei em estudar medicina, talvez para me dedicar à psiquiatria. Mas, eu já estava 
formado em direito, a profissão jurídica tem tantas vertentes, de modo que escolhi o magistério público.

EBJ - Mas a Solange não é formada em direito, e sim em ciências sociais.

SS - Acho que você viu pelo currículo, eu fiz liberal arts (humanidades, ciências humanas), no Uruguai. Casei-me, enviuvei aos 23 anos e deixei os estudos. Quando casei com Cláudio, que trabalhava com direito e sociologia do direito, resolvi fazer direito, já tendo o embasamento do liberal arts. Fui logo aceita nos Estados Unidos e comecei a estudar direito. Como o direito nos Estados Unidos começa com ciências sociais, com o embasamento em ciências sociais, acabei desistindo do curso de direito. Mas, a pósgraduação $^{2}$ e a livre docência ${ }^{3}$ foram em sociologia do direito.

EBJ - Isso foi logo no início dos anos sessenta, quando Cláudio tem uma passagem como professor visitante nos Estados Unidos ${ }^{4}$. O Cláudio foi como professor visitante...

SS - ... e eu como estudante. No Uruguai, em Montevidéu, estudei também o que quase toda a mulher que gostava de trabalhar naquele tempo estudava, matérias de secretariado. Quando casei com o Cláudio...

CS - Ela fez no Uruguai o Junior College, aquele sistema americano ${ }^{5}$...

SS - Internato mesmo, fechado...

CS $-\ldots$ metodista...

EBJ - Eu fiquei impressionada quando li os currículos de vocês pelos primeiros lugares. Mas, continuando, você se formou em direito em...

CS $-\ldots 1953 \ldots$

EBJ - Mas nunca advogou。

CS - Eu estagiei um ano em um escritório de advocacia.

EBJ - Ainda durante a faculdade?

CS - Essa estória é pitoresca. Ainda durante a faculdade... ou durante a faculdade ou logo depois, acho que estava no último ano da faculdade. Aconteceu o seguinte: passei um ano

\footnotetext{
${ }^{2}$ Pós-graduação lato sensu (especialização), concluída em 1964.

${ }^{3}$ Concluída em 1970, tese intitulada Controle Social e Direito (a defesa de tese em concurso de livre-docente atribuía o grau de doutor).

${ }^{4}$ Em 1961, Cláudio Souto foi Visiting Research Fellow no Southwestern Legal Center e Visiting Research Scholar na University of Columbia.

${ }^{5}$ Crandon Institute Junior College.
} 
no escritório, estudando direito processual. Era um escritório enorme, do irmão do Nehemias Gueiros, Esdras Gueiros. Eu devia estar no quinto ano, quando comecei. Quando me formasse, o Gueiros ia passar procuração para mim. Nessa ocasião, Amaro Quintas, um professor de história muito conhecido em Pernambuco, estava lecionando sociologia na Faculdade das freiras, Faculdade de Filosofia do Recife, que pertencia à Universidade do Recife, mais tarde, Universidade Federal de Pernambuco. Amaro Quintas perguntou-me se eu queria substituí-lo (ele, por sua vez, estava substituindo um outro professor de sociologia). Eram duas turmas de sociologia e ganhava-se uma miséria por mês. Eu disse então para o Gueiros, que ficaria muito honrado em ser advogado no escritório, mas que havia descoberto que a minha vocação não era a advocacia, que eu queria ser só professor. Naquele tempo não havia dedicação exclusiva, e eu não tinha ainda acesso, como professor, à Universidade Federal de Pernambuco. Fiz o doutorado em Direito. Em 1957 defendi a tese, mas não havia nenhuma garantia de emprego. Fiz a livredocência. Apesar de ser um concurso, a livre-docência era, em si mesma, só um título, pois os catedráticos é que mandavam mesmo. Eu agradeci ao Gueiros, mas a minha vocação não era aquela. Ele compreendeu muito bem, e fui ser professor.

\section{EBJ - E começou dando aula de sociologia.}

CS - Sociologia Geral, não era ainda sociologia do direito ${ }^{6}$.

\section{EBJ - Não existia ainda a sociologia do direito enquanto disciplina.}

CS - Nesse período eu comecei a fazer o doutorado, mais ou menos concomitantemente. E pronto. O pessoal da família, muito angustiado por eu querer ser professor, decidiu arranjar-me um emprego. Eu estava em casa e chegou uma comunicação para fazer exame de saúde, pois havia sido nomeado - naquela época não havia concurso não - promotoradjunto da Justiça Militar do Estado. O promotor titular era deputado, não estava em exercício, e eu ia assumir a função, ganhando duas vezes mais do que um professor catedrático. O Governador do Estado era o General Cordeiro de Farias. Este cargo havia sido conseguido através de um deputado, uma espécie de filho político de meu pai, que, por gratidão, me arranjou um emprego sem me consultar. Ninguém me consultou, e eu

\footnotetext{
61954.
} 
disse que não queria não. Saiu então o emprego de instrutor contratado na faculdade de direito.

SS - Mas você já tinha concluído o doutorado, então?

CS - O doutorado eu concluí logo. A tese deveria ter sido defendida em 1956, mas como sempre o processo demorava, eu a defendi em 1957.

$E B J-A$ tese foi sobre o que?

CS - "Da Inexistência Científico-Conceitual do Direito Comparado".

EBJ - Eu já havia visto menção desse trabalho, mas não sabia que era a tese de doutorado.

CS - Foi um escândalo, pois não há uma citação no texto, só no prefácio. Argumentei: "Mas minha gente, estou tentando apresentar uma perspectiva relativamente nova. Citar por que?". No prefácio citei, mas foi um escândalo. Na tese de livre-docência fiz o contrário, carreguei na citação, embora fora do texto principal ${ }^{7}$. Eles também reclamaram. EBJ - Continuando, em 1962...

CS - Eu era professor... na prática era assistente de direito constitucional de Pinto Ferreira. Fiz a livre-docência, não em direito constitucional (e o Pinto Ferreira não gostou disso), mas em Introdução, que era a disciplina mais próxima da sociologia do direito, que era o que eu amava. Eu estava ensinando direito constitucional, mas gostava mesmo era de sociologia do direito. Introdução era menos distante, era matéria propedêutica.

EBJ - Antes você já tinha feito uma pesquisa sobre lei agrária...

A Sociologia Jurídica, como atividade de pesquisa sociológica empírica, surge no Brasil ligada de perto à prática do direito. Na verdade, em 1960 tivemos a honra de realizar para o Instituto Joaquim Nabuco de Pesquisas Sociais uma investigação empírica aplicada sobre a receptividade social a um projeto de lei agrária para o Estado de Pernambuco, projeto esse que chegou a ser apresentado à Assembléia Legislativa do Estado. Tudo indica que assim se abria no país, sob a égide de uma conexão íntima entre Sociologia do Direito e prática legislativa, a fase das pesquisas sócio-jurídicas empíricas (1978, p. 7).

\footnotetext{
${ }^{7}$ A tese, Da Irrealidade Jurídico-Definitiva do Direito Natural, Nova Visualização do Fenômeno Jusnaturalista (1958), foi defendida na Faculdade de Direito, hoje Universidade Federal de Pernambuco, em 1962. Na revisão da entrevista, Cláudio Souto acrescentou a seguinte observação: “Apesar de ter sido escrita em dois volumes, só aceitaram a defesa do primeiro volume. A defesa dessa tese se fez em clima de turbulência: a tese já era sociológica e contrariava preconceitos jusnaturalistas e juspositivistas ao mesmo tempo... Talvez, pior que isso: tentava ser criativa no âmbito de uma teoria geral do direito".
} 
CS - Isso foi no [Instituto] Joaquim Nabuco [de Pesquisas Sociais]...

EBJ - Como foi esse contato com a Fundação Joaquim Nabuco?

CS - Gilberto Freyre era uma pessoa muito encantadora que, quando encontrava algum jovem estudioso, procurava atraí-lo para a Fundação. Eu participei dos tempos iniciais do Joaquim Nabuco, que na época era o Instituto Joaquim Nabuco de Pesquisas Sociais. Não era o início total, mas os inícios ${ }^{8}$. E lá eu disse que queria fazer sociologia do direito.

SS - O ano, você se lembra, Cláudio?

\section{EBJ - Foi pelo finalzinho dos anos cinquenta?}

SS - Você viajou para os Estados Unidos em 1961, e em 1960 você já estava pelo interior. CS - Pronto, exatamente. Foi uma pesquisa sobre a receptividade a um projeto de lei agrária. Eu elaborei este projeto, mas o texto constitucional não possibilitava fazer muita coisa. Um primo meu, deputado estadual, chamado Luis Souto Dourado, já falecido, apresentou o projeto na Assembleia Legislativa do Estado. É claro que o projeto não foi aprovado, pois era um projeto de lei que mexia em interesses poderosos. Mas, como pesquisa foi interessante. Evidenciou-se uma forte receptividade, na época. Eu não sei até que ponto houve muita confiabilidade, porque nós não tínhamos condições de aplicar os questionários. Nós distribuímos os questionários para os agentes d[a] [Fundação] IBGE [Instituto Brasileiro de Geografia e Estatística]. Se as pesquisas do IBGE são confiáveis, essa também é; se não são...

\section{EBJ - Essa foi a primeira pesquisa empírica.}

CS - Tudo indica que foi a primeira, sócio-jurídica, do país. Logo depois houve uma....

EBJ - Joaquim Nabuco, final dos anos cinquenta, início dos anos sessenta. Desculpe a pergunta mais pessoal, vocês já estavam casados?

SS - Casamos em 25 de dezembro de 1960.

CS - Ela não era ainda casada comigo, mas acompanhou muito dessa pesquisa.

SS - Por isso é que eu estava tentando me lembrar... Foi final de cinquenta....

CS - Nós íamos na camionete do Instituto...

SS - ... com chofer do Instituto, em um jipe...

\footnotetext{
${ }^{8} \mathrm{O}$ Instituto Joaquim Nabuco de Pesquisas Sociais foi fundado em 1949.

${ }^{9}$ A pesquisa foi realizada em 1960.
} 
CS - A carta branca era total. Gilberto Freyre não tinha a menor interferência.

SS - ... isso era muito bonito...

CS - Nós podíamos encaminhar a pesquisa como quiséssemos, não havia problema. Nunca houve qualquer interferência, nunca vi interferência dele sobre pesquisador.

\section{EBJ - E como foi a decisão de ir para os Estados Unidos?}

CS - Isso foi interessante. Chegou uma bolsa da Fulbright para o Instituto e perguntaramme se eu queria. Naquele tempo, era assim, a instituição recebia a bolsa e indicava...

\section{EBJ - Já era uma bolsa para um lugar determinado nos Estados Unidos...}

CS - Foi-me oferecida a possibilidade de ir para Yale. Mas a Solange tinha feito o início da graduação em uma instituição metodista. Então nós resolvemos ir para a Universidade Metodista do Texas, pois era mais fácil a adaptação dela ${ }^{10}$. Havia lá um Southwestern Legal Studies e era, creio, a maior universidade do Sudoeste, na época pelo menos, não sei atualmente. Depois nós fomos para Nova Iorque, para a Universidade de Columbia.

\section{$E B J$ - Foi um ano todo de bolsa?}

SS - Um ano, mas só para ele.

CS - Essa bolsa na verdade era de dez meses, mas, terminados os dez meses, eu pedi um adiamentozinho...

SS - Ele estava escrevendo um livro...

CS - ... e recebi a resposta de que podia ficar. Entendi que era para ficar remunerado, mas não era. Quando soube, telefonei para Washington, zangado (naquela época eu não era tão religioso, de modo que me zangava mais) e a senhora me disse: "Doutor Souto... esse episódio todo teve uma vantagem, eu estou vendo que o seu inglês está fluente". Nós procurávamos acordar tarde, para tomar café e "pular" o almoço, e jantávamos cedo...

SS - Para não pedir dinheiro. Nasceu um neném lá, eu estudando e Cláudio escrevendo um livro.

CS - Nasceu um menino nosso lá, Solange teve um menino em uma enfermaria coletiva, e não tinha berço em casa...

SS - ... foi colocado em uma mala...

CS - Nós morávamos em Nova lorque, perto do Harlem.

\footnotetext{
${ }^{10}$ Graduação em Ciências Sociais pelo College of Arts and Sciences da Southern Methodist University.
} 
SS - ... na 113 com Broadway.

CS - Uma visitadora social foi ao nosso apartamento, um quarto grande com banheiro...

SS - ... era um hotel antigo, de mármore, da década de trinta, que "virou" uma grande hospedaria.

CS - ... o Baby Souto era também americano, pois nasceu lá. A visitadora social foi fazer a visita...

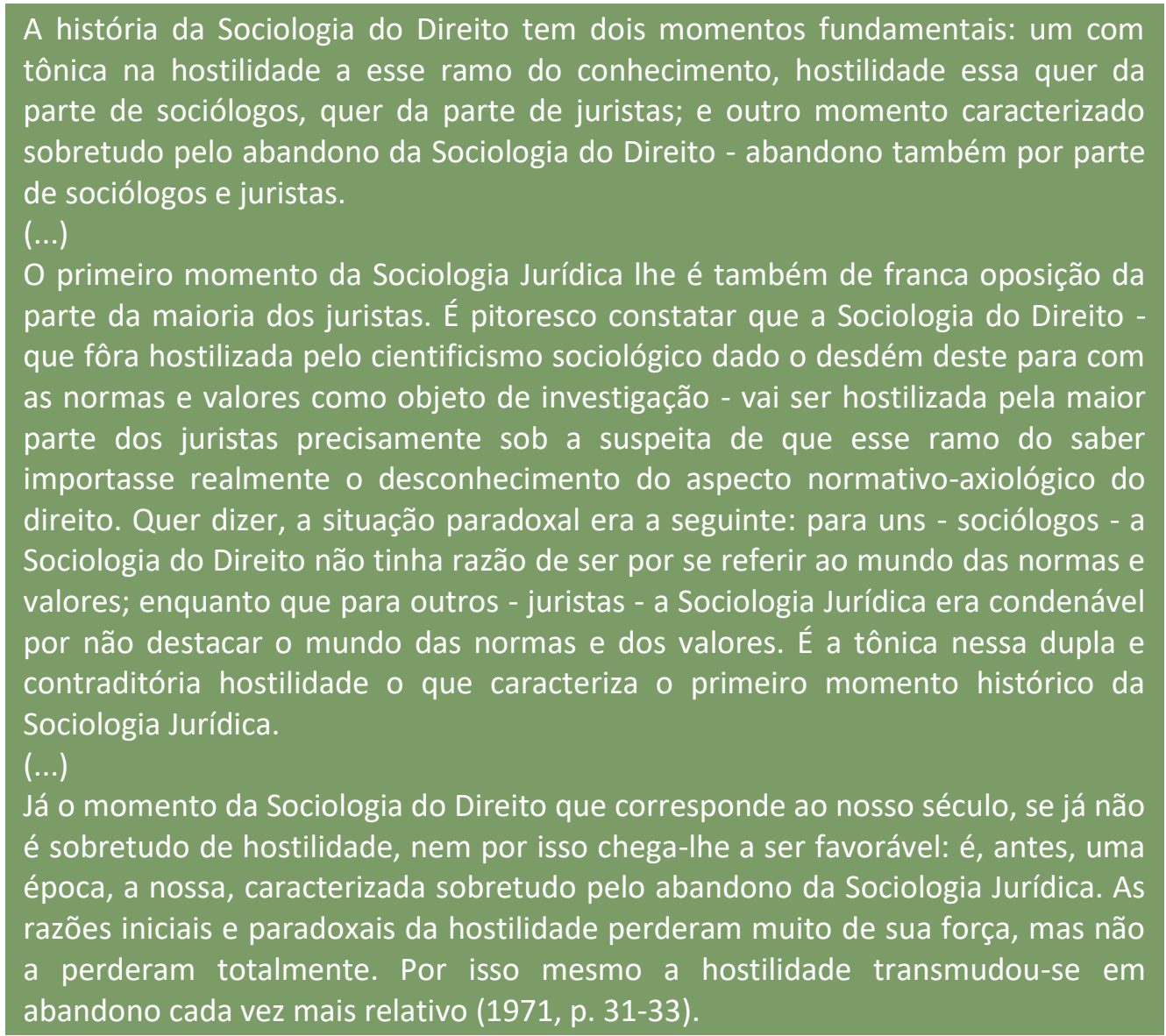

SS - ... para ver se tudo estava em ordem, se nós estávamos tratando bem a criança, se ela dormia direito...

CS - ... e o Baby Souto... estava em uma mala... cheio de roupas muito bonitas, que os avós mandaram...

SS - mas na mala, pois não comprei berço. Nós só fazíamos estudar... Ele ficava na mala em cima de uma mesa... 
CS - O Baby Souto hoje em dia é professor da Universidade Federal de Pernambuco, doutor em biologia pela Alemanha.

EBJ - Solange começou a estudar direito, mas desistiu.

SS - Tinha começado direito, o básico de direito, mas desisti. Estava arriscada a não vir ao Brasil de logo, pois o Brasil não aceitava os meus

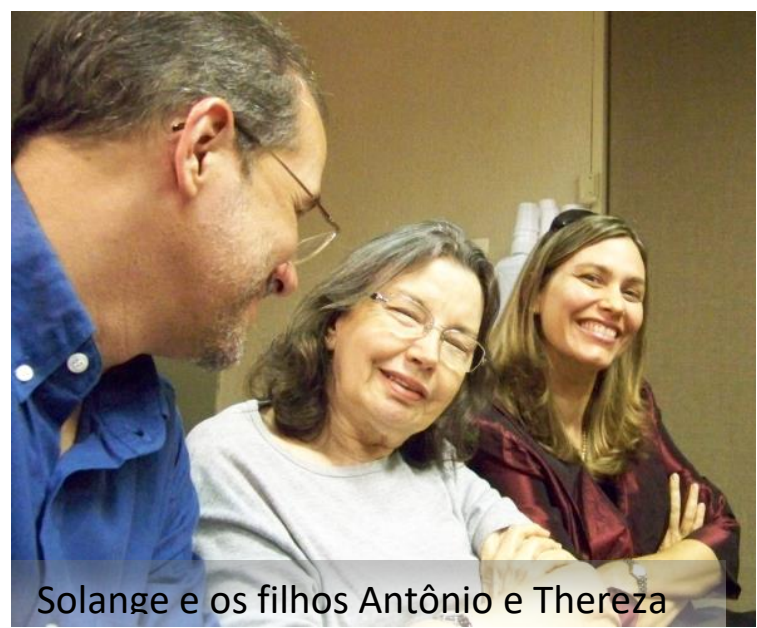
créditos. Naquele tempo era dificílimo, em razão do sistema de créditos lá e o sistema seriado aqui, bem tradicional. Finalmente a [Universidade] Católica [de Pernambuco] aceitou, claro que eu perdendo muitos créditos, e fiz o último ano de sociologia aqui ${ }^{11}$. Naquele tempo, era ciências sociais. Eu fiz somente o último ano e a licenciatura aqui.

EBJ - E essa experiência nos Estados Unidos em termos teóricos da sociologia do direito, em termos de ideias...

CS - Naquela época não havia muita receptividade à sociologia do direito nos Estados Unidos. Isso começou um pouquinho mais tarde.

SS - Era mais filosofia...

CS - Não havia muita receptividade. Fui para os Estados Unidos porque estava com uma bolsa na mão, ia casar, era uma oportunidade de me afastar. Em parte foi isso. Mesmo na Europa naquela época, não havia muita... havia o [Georges] Gurvitch...

SS - ... que havia andado aqui na Faculdade de Direito nos anos cinquenta, dando um curso de sociologia...

EBJ - Voltando ao Brasil, surge a ideia de criar a disciplina sociologia do direito na Universidade Católica de Pernambuco...

CS - Vou contar para você em primeiríssima mão. Queriam que eu escrevesse, mas não escrevi. Você conhece a história da sociologia do direito em Pernambuco, está no livro, mas a história da sociologia do direito na Faculdade de Direito do Recife você não conhece. Eu estava até pensando em escrever, o artigo teria o título “Memória para uma história acadêmica alternativa"... "alternativa" está na moda. Toda a história das disciplinas

\footnotetext{
${ }^{11}$ Curso concluído em 1962, tendo obtido o 10 lugar entre todos os concluintes de todos os Cursos da Faculdade de Filosofia, Ciências e Letras naquele ano.
} 
acadêmicas na Faculdade de Recife é praticamente uma história da dogmática. A própria filosofia do direito desapareceu, retornou agora, em parte por força de lei, essa Portaria nova do MEC [Ministério de Educação] que estabelece a obrigatoriedade da filosofia do direito.

Esse momento subsequente da década de 60 , que igualmente nos honra ter
vivido, teve de ser - momento de constituição sistemática que era - mais teórico
que aplicado. Nele lecionamos, quer em graduação, quer em pós-graduação,
sobretudo uma sociologia geral do direito, pois a disciplina mesma estava ainda
em formação conceitual e era preciso, didaticamente, introduzir algo em nível
básico, ao lado da Introdução ao Direito, como matéria acentuadamente
dogmática, e da Filosofia Jurídica, como matéria filosófica. De maneira
correspondente, a pesquisa empírica se revestiu de caráter teórico (1978, p. 8).

Em 1963, Pinto Ferreira foi para o Senado, como suplente de José Ermírio de Moraes. Eu era assistente de direito constitucional, que era a cadeira dele, e tinha a livre-docência de introdução. Na época, o livre docente podia, usando a terminologia de então, reger cátedras, ser interinamente catedrático. Eu fiquei na cátedra então. Naquele tempo eu já era inteiramente favorável à reforma universitária, contra esse negócio de cátedra. Nessa substituição, eu tinha o mesmo poder do catedrático, tinha assento na congregação. $\mathrm{O}$ diretor da faculdade brincava: “O voto do Professor Cláudio Souto, nós já conhecemos, ele vota com os estudantes". Eu me comportava como estudante, porque era muito jovem. Tinha afinidade total com os estudantes sobre a reforma universitária. O representante estudantil e eu... pronto, éramos a mesma coisa. Pensei então: “Estou nessa cátedra, então vou ver se consigo trazer a sociologia do direito para dentro da faculdade". Os estudantes naturalmente apoiariam. Mas não havia ambiente para a iniciativa. Isso foi em 1963. Não havia nem sala para dar aula de sociologia do direito... Eu procurei uma sala, pensei na biblioteca, no terraço da biblioteca, mas na biblioteca havia um barulhozinho. 0 regime era seriado, a faculdade antiga, o prédio é muito bonito, mas antigo, as salas totalmente ocupadas pelas disciplinas regulares e rigidamente delimitadas do curso de bacharelado. O curso de doutorado naquela época estava suspenso. Mas era preciso começar de qualquer maneira. Eu perguntei na turma em que ensinava quem estaria interessado em estudar sociologia do direito. Uns dez ou doze alunos dessa turma de 20 ano mostraram interesse. Teve de ser inteiramente informal, porque não havia condições 
para outro procedimento. Sabe onde foram dadas essas aulas? Sabe onde começou a sociologia do direito como disciplina? No Parque Treze de Maio, que fica em frente da Faculdade. Hoje em dia seria impossível, pois todo mundo seria assaltado. Mas, naquela época, era uma praça agradável... Foi assim que começou a sociologia do direito, da maneira mais informal possível. Mas não foi possível fazer um registro oficial da disciplina como matéria institucionalizada. Ela foi institucionalizada na Universidade Católica [de Pernambuco] em 1962.

Em seguida viria o momento da investigação empírica e do ensino sistemático da Sociologia Jurídica entre nós, com o estabelecimento, em 1963, da Divisão de Ciência do Direito do então Instituto de Ciências do Homem da Universidade do Recife, hoje Universidade Federal de Pernambuco, dedicada essa Divisão à Sociologia Jurídica e operando em nível de pós-graduação. E em 1964 começava a funcionar, na Faculdade de Direito da Universidade Católica de Pernambuco, em seu currículo de Bacharelado, a primeira cadeira de Sociologia Jurídica do Brasil $(1978$, p. 8).

EBJ - Também uma proposta sua...

CS - Foi, 1962, no papel.

SS - Mas quando foi lecionada?

EBJ - A partir de 1964.

SS - Eu estava pensando nisso, começou-se a ensinar regularmente em 1963, mas na pósgraduação (especialização) da Universidade Federal de Pernambuco.

CS - Agora, os antecedentes disso. Aquele livro que você conhece, do Evaristo de Moraes Filho $^{12}$. Depois, a tese de doutorado de Vamireh Chacon foi sobre sociologia do direito. E ligado à [Universidade] Católica [de Pernambuco] surgiu o primeiro livro sistemático de sociologia do direito: nosso Fundamentos da Sociologia Jurídica, de 1968. A primeira edição foi uma publicação em off-set da Católica, que depois se tornaria, aumentado, o Introdução ao Direito como Ciência Social. Porém o livro de Miranda Rosa, de 1970, foi o que mais contribuiu para a divulgação da sociologia do direito no país, pois alcançou um número extraordinário de edições.

\section{EBJ - Na Católica havia uma maior receptividade para a disciplina?}

12 O problema de uma sociologia do direito (1950). 
CS - Lá não havia problema não. Era a idade de ouro da Faculdade de Direito da Católica. Os padres eram muito abertos. O Padre Grangeiro, Diretor, abertíssimo. Este pessoal estava movimentando o início da Faculdade, uma coisa nova... Houve pleno ambiente, diferentemente da Faculdade de Direito do Recife, pois não havia lá poder de interesses investidos.

\section{EBJ - E quando foi formalizada a disciplina na Faculdade de Direito da Federal?}

CS - Bem depois da Católica, bem depois mesmo. Cheguei a ir para a Universidade de Brasília, pois aqui o ambiente era muito fechado em termos de sociologia do direito. Paulo Freire que foi meu professor amigo no colégio e do qual eu tinha muita aproximação, pois participei de certo modo do SEC, Serviço de Extensão Cultural, de onde parece que surgiu o método Paulo Freire, sugeriu meu nome a Darcy Ribeiro quando este estava ainda armando a Universidade [de Brasília]. Perguntou-me se eu queria ir... Naquele tempo eu era jovem, não tinha medo de avião, eu vivia de avião para cima e para baixo.

EBJ - Corre atualmente que você não viaja ... mas, pelo seu currículo, para quem não viaja você viajou bastante...

Estranhou-se na época que professores e estudantes pós-graduados da Divisão, oriundos, quase todos, do altamente urbano da Faculdade de Direito do Recife, nos votássemos a uma espécie de exílio voluntário em meio ao barro, à poeira e à relva daquela futura Cidade Universitária, então ainda campestre e ainda com a pobreza das coisas campestres. Mas foi assim - e dificilmente poderia ter sido de outro modo - que se institucionalizou a Sociologia do Direito no país (1981, p. vii).

CS - Há duas fases. A em que não tinha medo de avião e a posterior. Foi justamente um dos padres da Católica, um matemático, professor de física, Pe. Machado, que me disse: "Cláudio, avião cai, pela probabilidade pode cair...". Fomos para Brasília, eu entusiasmadíssimo de criar em uma universidade central, no Distrito Federal, a disciplina sociologia do direito. Ao chegar a Brasília, fui conversar com Darcy Ribeiro, aquela simpatia... O apelido dele era "mosquito elétrico", muito ativo... Darcy Ribeiro me disse que eu poderia ensinar o que quisesse ... (notei logo que ele não estava particularmente interessado em sociologia do direito) ... desde que fosse para os Estados Unidos, por dois anos, para estudar informática e informatizar a jurisprudência do Supremo Tribunal Federal. Na época era uma coisa avançadíssima, mas... não "batia" comigo. 
Delicadamente, eu não quis dar um não e disse que ia pensar. Mas não aceitei, pois ia me afastar da sociologia do direito. Foi a minha sorte, pois se tivesse aceito teria tido muitos problemas mais tarde, pois os professores daquela época não eram professores de confiança do regime governamental posterior. Todos ou quase todos saíram da Universidade em massa. Eu escapei dessa diáspora. Voltei então para o Recife, para grande satisfação de minha mãe, que estava triste com a minha ida para Brasília. Um dos motivos que pesavam era justamente a família aqui. Quando voltei, Paulo Freire veio com outra proposta: "Olhe, vai ser fundado um Instituto de Ciências do Homem. Que tal você fazer o que você queria fazer nesse Instituto?". Eu estava na regência daquela cátedra. Foi um escândalo, porque deixei a regência da cátedra, considerada importantíssima, para ir para o Instituto, que não tinha nada, era no restaurante da Cidade Universitária. A Cidade Universitária não tinha nada na época, totalmente primitiva, campestre.

SS - Você saiu então da Faculdade de Direito.

CS - Saí da Faculdade de Direito para o Instituto. No início, eu ainda estava ligado, posto à disposição. Eu tinha outro cargo, de professor, em Ciências Econômicas, a disciplina era instituições de direito público, e na Faculdade de Direito era direito constitucional. Fui posto à disposição. Assim que foi possível, fiz a transferência para lá...Havia a Divisão de... SS - ... Sociologia, Psicologia...

CS - E uma Seção de Ciência do Direito, ligada à Divisão de Sociologia ${ }^{13}$. Aconteceu outra coisa pitoresca. O Marco Antonio Maciel era presidente do DCE [Diretório Central dos Estudantes] e participou da segunda turma da Seção da Ciência do Direito, como estudante. Naquele tempo o Marco tinha uma posição política um tanto à esquerda, defendendo "socialização e liberdade", em contraposição a uma postura esquerdista radical. Ele me disse: "Cláudio, você não acha um absurdo ser seção e não divisão?!". Bem, eu era suspeito, mas achava que deveria ser uma divisão porque, afinal, correspondia a toda uma área, a do direito, na parte de pesquisa e de pós-graduação. Além da sociologia do direito e da sociologia, seria possível haver outras disciplinas, antropologia do direito, etc. Como eu não queria atuar nesse sentido, pois era suspeito, Marco Maciel

\footnotetext{
${ }^{13}$ A Seção de Ciência do Direito começou a funcionar em 11 de agosto de 1963, na Universidade Federal de Pernambuco.
} 
"voluntarizou-se" para falar com o Reitor, o João Alfredo [da Costa Lima]. Da noite para o dia virou uma divisão, aumentando a sua possibilidade de atuação. Nós fizemos pesquisa e começou o ensino de pós-graduação.

EBJ - A divisão oferecia um curso em que área?

SS - Especialização em direito... Especificamente, preparação em pesquisa sócio-jurídica...

O principal objetivo desse Departamento era preparar, em colaboração com
outros Departamentos do mesmo Instituto, bacharéis em Direito para serem
cientistas sociais, através da sua formação em cursos não ordinariamente
incluídos no Currículo Jurídico (tais como Sociologia do Direito, Métodos e
Técnicas de Pesquisa Social, Estatística, Desenvolvimento Sócio-Econômico e
Direito, Sociologia Geral, Sociologia Industrial, Sociologia do Desenvolvimento,
Psicologia Sócio-Jurídica, Antropologia Jurídica) (1981, p. 58).

CS - ... preparação em teoria e pesquisa sócio-jurídica.

\section{EBJ - Solange, você fez o curso?}

SS - Fiz parte da primeira turma ${ }^{14}$.

CS - Na primeira turma estudou Walter Costa Porto, figura exponencial dos bastidores de Brasília, muito ligado a Marco Antonio [Maciel]. Havia gente à esquerda, também, como Luís Pandolfi, advogado ilustre e professor da Faculdade de Direito do Recife. O Instituto era um instituto de pesquisa, que dava uma preparação para a pesquisa em sociologia, em psicologia, depois também em história e em economia. Desse instituto surgiu a pósgraduação. Houve uma reforma da reforma, acabaram os institutos de pesquisa. Surgiu o dogma da indissociação do ensino e da pesquisa, a partir do qual as divisões foram dissolvidas ${ }^{15}$.

\section{EBJ - Em que ano isso aconteceu?}

CS - Década de setenta. Eu tentei... nós temos raízes afetivas, eu era afetivamente ligado à Faculdade de Direito do Recife, onde fiz a graduação...

SS - Foi muito no início de setenta.

\footnotetext{
${ }^{14}$ Solange Souto concluiu em 1964 o I Curso de Teoria e Pesquisa Sócio-Jurídica do Instituto de Ciências do Homem, obtendo o 1 일. lugar.

${ }^{15} \mathrm{Em}$ função da reforma universitária, o Instituto de Ciências do Homem foi absorvido pelo Instituto de Filosofia e Ciências Humanas, sendo as atividades da Divisão de Ciência do Direito absorvidas pelo Programa Integrado de Mestrado em Economia e Sociologia da Universidade Federal de Pernambuco, onde se transformou, primeiramente, na área de concentração "Controle Social" e, mais tarde, na área de concentração "Sociologia Jurídica".
} 
CS - Quando foi extinto o Instituto, tentei localizar a divisão na Faculdade de Direito, mas continuava sem ambiente. Fomos então para o Instituto de Filosofia e Ciências Humanas, onde fomos incorporados ao mestrado em sociologia.

SS - Começamos com sociologia e terminamos com sociologia porque a Faculdade de Direito não nos absorveu, nem no início nem posteriormente.

Na Faculdade de Direito do Recife conhecemos de perto esses esforços: no início
o apoio das Direções Mário Baptista e Pinto Ferreira, confirmado depois pela
Coordenação Lourival Vilanova, à inserção da disciplina no Curso de Mestrado em
Direito; e recentemente o largo passo da Direção Francisco de Assis Rosa e Silva
Sobrinho, que encaminhou histórico documento solicitando o ensino da
Sociologia Jurídica como disciplina obrigatória da formação do bacharelado do
estudante de Direito.
Em artigo publicado na Alemanha, há cinco anos, prevíramos esse
desenvolvimento (Souto, 1972: $249-250)$. A conclusão de tal escrito permanece
possivelmente válida: se de fato se consolida a nova tendência para a Sociologia
Jurídica dessas duas tradicionais e prestigiosas Faculdades de Direito - e o ano do
sesquicentenário é aqui bastante simbólico -, tal consolidação pode decerto
implicar um melhor reconhecimento da matéria no país com consequências
teórico-práticas consideráveis na educação jurídica brasileira (1978, p. 117).

CS - Eu continuei tentando ao longo dos anos. Um dos diretores, Mário Baptista, fez de tudo para colocar as atividades de pesquisa da antiga divisão na Faculdade de Direito... isso já na década de oitenta?

SS - Eu tenho a impressão que ainda era década de setenta

CS - E não conseguiu. Pinto Ferreira, que organizou o mestrado em direito, queria que eu participasse do mestrado, mas não me chamavam. A sociologia do direito era perigosa em um ambiente kelseniano.

SS - Era também o problema da sociologia ser sempre considerada como uma coisa subversiva.

\section{EBJ - 1964 tem alguma influência nesse processo?}

CS - Eu tenho impressão que tem uma influência indireta, direta não. O problema é mais acadêmico, pois a sociologia do direito é uma matéria perigosa por sua própria natureza, em relação à perspectiva kelseniana. "Não é direito, é sociologia", e não deve estar na faculdade de direito.

SS - Há as duas influências, a influência acadêmica da dogmática jurídica e a influência do movimento de 64 ... 
CS - ... mas não foi uma influência ostensiva...

SS - ... ostensiva não.

CS - Aconteceu o seguinte. Houve um encontro do CNPq, promovido em 1974 por Joaquim Falcão. Lourival Vilanova foi a esse encontro...

SS - ... no Rio de Janeiro, foi na PUC...

CS - ... Vilanova era o coordenador do Mestrado. Vilanova percebeu que eu não estava talvez tão... Solange, quantos anos eu tinha naquela época?

SS - ... radical

CS - ... tinha mais de quarenta?

SS - Quarenta e dois.

CS - Eu já estava mais assimilável para o Vilanova, que me mandou um recado através do [Nelson] Saldanha, que ensinava no mestrado, perguntando se eu queria ensinar sociologia do direito. Então eu fui para o mestrado ${ }^{16}$. Sociologia do direito era optativa. A partir daí foi o retorno à Faculdade de Direito. Como eu estava ensinando na pós-graduação, pude, no momento oportuno, sugerir a disciplina para a graduação. Mas, na graduação a sociologia do direito só entrou através de movimento estudantil. Os estudantes perceberam a importância e uma heroína, Ana Lúcia [Falcão], liderou a reivindicação. A matéria foi então introduzida como optativa na graduação. Muito recentemente se tornou obrigatória na pós-graduação, também pela atuação do movimento estudantil. 0 representante estudantil, Elias [de Moura Rocha], capitaneou o movimento. Ela é obrigatória no mestrado e no doutorado, e já é obrigatória na graduação por força de decisão federal. Luciano Oliveira, que estava ensinando ultimamente na graduação, vai lecionar também na pós-graduação, comigo.

SS - Você saiu em 63, voltou em...

CS - Ensinei na graduação com Solange durante quatro anos ${ }^{17}$ e na pós-graduação ${ }^{18}$, no mestrado de direito, se bem que não desde o início do mestrado. Quanto à graduação,

\footnotetext{
161674.

17 1986-1990.

181974 até agora.
} 
porém, já antes de 1986, sobretudo Solange ensinava, como Sociologia II, do ciclo geral, sociologia jurídica às turmas de Direito.

EBJ - Sobre a Alemanha ${ }^{19}$.

CS - Sempre gostei muito da Alemanha, tanto pela influência germânica na faculdade de direito, como pela influência de Pinto Ferreira, muito ligado à bibliografia alemã. Desde estudante, eu me interessava, estudava alemão...

SS - Por que você não conseguiu inicialmente a bolsa?

CS - Porque era recém-formado. Depois consegui, pela Fundação Alexander von Humbolt.

\section{EBJ - E por que escolheu Colônia?}

CS - Em Colônia havia um professor... Não podia pensar em ir através da sociologia do direito, que praticamente não existia. Eu havia escrito um livro sobre direito internacional privado, uma Introdução Crítica ao Direito Internacional Privado ${ }^{20}$, e Gerhard Kegel era professor dessa disciplina. O anfitrião foi Kegel. Mas quando cheguei lá, eu disse: "Professor, vou escrever sobre sociologia do direito". Ele riu, porque era dogmático, e brincou: "O que é isso? Eu queria transformá-lo em um homem prático...". Ele é uma pessoa muito cordial, interessante...

\footnotetext{
Nossa investigação é uma pesquisa exploratória básica que estudou o sentimento e a ideia de justiça entre os estudantes estrangeiros na Universidade de Colônia, em 1965, com um período de permanência na Alemanha de não mais de um ano, tentando três novas perspectivas: 1 . é baseada na distinção, por abstração, de sentimento e ideia de justiça; 2 . investigou estudantes de diferentes nacionalidades sob a suposição de que o problema da justiça é um problema do homem; 3. conduziu-se com referência a uma teoria da justiça, fundando-se no seguinte quadro hipotético: existência, permanência e variabilidade de um sentimento do dever ser, associação necessária desse sentimento com uma ideia, que pode estar a) de acordo com a ciência, b) de acordo com a metaciência, c) de acordo com o conhecimento das circunstâncias particulares de um caso ou d) pode ser outra ideia.

(...)

Outros resultados foram obtidos, tais como: 1 . a injustiça parece ser sentida mais do que a justiça; 2. o sentimento de justiça é caracterizado como agradável e, inversamente, o sentimento de injustiça como desagradável; 3 . o sentimento de justiça e injustiça parece ser mais forte na adolescência que na idade adulta, enquanto de maneira inversa a ideia de justiça e injustiça parece ser mais forte na idade adulta que na adolescência; 4. uma maioria muito alta de respondentes reage desfavoravelmente à imposição de uma lei errada (incorreta); 5. uma
}

\footnotetext{
${ }^{19}$ A primeira ida de Cláudio e Solange Souto à Alemanha foi em 1965.

${ }^{20}$ (1964).
} 
SS - ... com humor alemão...

CS - ... deu todo o apoio...

EBJ - Foi a pesquisa sobre sentimento de justiça?

CS - Ele determinou que um assistente me desse todo apoio. Ele até admitiu a possibilidade... Naquela época a Alemanha não estava com qualquer superpopulação. Vinte anos depois da guerra, a população ainda era muito rarefeita. Ele sugeriu que, se eu conseguisse fazer a ligação entre sociologia e direito, poderia ficar na Alemanha. Mas eu não queria nem pensar nisso porque minha mãe estava doente de câncer. E era muito difícil para um estrangeiro, mesmo naquela época, quando ainda era mais fácil. A escolha da Alemanha foi justamente porque eu sempre tive muita sintonia com a maneira teórica de ser dos alemães.

SS - Já citava muito alemães naquela época. Eu me lembro que datilografando as bibliografias de Cláudio, era tanta coisa em alemão...

$E B J$ - A influência francesa é pouca em sua obra, pelo menos a partir da bibliografia. CS - A minha geração, de qualquer maneira, tem uma forte influência francesa.

SS - Mas a sua é mais alemã.

CS - Isso era mais uma questão voluntária. Quem não se dedicasse, como autodidata, à influência alemã, recebia a influência francesa. A influência nas faculdades de direito era acentuadamente francesa.

EBJ - Nelson Saldanha, por exemplo. Você é mais voltado para a pesquisa empírica.

CS - Na verdade, sou mais voltado para teoria. Fiz bastante pesquisa empírica porque não havia naquela época quem fizesse. Mas o meu gosto mesmo, a vocação, é teoria, é colocar a coisa em um ponto em que seja testável. Se uma outra pessoa puder testar... prefiro. Não tenho acentuada a vocação de pesquisador empírico. Sou pesquisador no sentido mais teórico...

SS - Mas como também não havia o pesquisador...

CS - A sociologia do direito não podia ser desenvolvida sem a parte da pesquisa empírica. Por esse motivo criou-se a Divisão, que foi fundada para fazer pesquisa. Mas nunca perdi o 
vício do teórico. Se você me perguntar, o que você gosta mais, fazer teoria ou fazer pesquisa? Fazer teoria. Não sei se vai sair o nosso primeiro artigo em francês (para a revista Droit et Société), uma coisa um pouco abstrata, proponho uma teoria mais geral unificada do mental e do social, alguém influente pode estranhar ${ }^{21}$. A publicação foi confirmada, mas está demorando. A Alemanha tem sido tolerante para comigo, publicando inclusive sobre essa possível unificação ${ }^{22}$. Tenho um artigo em francês, mas foi publicado no Japão ${ }^{23}$. Você vê, naquela época, qual era a língua de difusão para o direito? No Instituto Japonês de Direito Comparado era o francês...

EBJ - Durante a estada na Alemanha você entrou em contato com Renato Treves?

CS - Meu contato com Renato Treves foi por cartas, nunca cheguei a conhecê-lo pessoalmente.

EBJ - Nessa época não participou de nenhuma reunião do Research Committee on the Sociology of Law?

CS - Não, nessa época já tinha horror de avião.

SS - Ficava sempre mandando trabalhos.

CS - Era época de Segerstedt na Suécia. Eu cheguei a "armar" uma passagem para a Suécia, vê como eu estava disposto, mas acabei não indo porque a Solange estava muito grávida.

\section{EBJ - E Carbonnier?}

SS - Só cartas.

CS - O livro - Flexible Droit (1979) - dele é posterior a essa época, 1969.

EBJ - Primeira ida à Alemanha. Depois você foi de novo para a Alemanha em 1970...

O fundamental do pensar sociologicamente estaria na reflexão crítica e, sobretudo, criativa. Não estaria necessariamente no pensar "grande", não necessariamente na grande teoria, mas se situaria essencialmente no pensar "novo", uma forma qualquer de novo. Uma forma qualquer de novo que se distinguisse, no mínimo que fosse, do mundo social que lhe é anterior e lhe é fortemente condicionante (1987, p. 53).

\footnotetext{
21 "Les Règles de la Méthodologie Sociologique: un Siècle Après".

22 (1994).

${ }^{23}(1962)$.
} 
CS - Nós fizemos uma segunda pesquisa sobre mudança social ${ }^{24}$. Foi uma coisa meio tumultuosa, pois eu estava doente. Felizmente foi conosco uma jovem, Glória [Barros] ${ }^{25}$, que ensinava na UNICAP [Universidade Católica de Pernambuco], e foi conosco em parte para ajudar com os meninos. Ela pôde ajudar a levar essa pesquisa para a frente, pois adoeci. Depois fui, em 1982, para a Universidade de Bielefeld, fazer um doutorado.

SS - Esse doutorado foi em ciências sociais.

CS - Ciências sociais, mas teoria sociológica. O título que dão em Bielefeld é de doutor em ciências sociais. Eles não dão título de doutor em sociologia, apesar da faculdade ser de sociologia. A nossa tese foi sobre teoria sociológica. "Fundamentos científicos mais gerais do social" é o título.

\section{EBJ - Você trabalhou com [Niklas] Luhmann?}

CS - Luhmann era o orientador. Mas um orientador muito compreensivo. Eu já tinha uma certa idade, vamos dizer assim, um pouquinho de maturidade, de modo que ele me soltou completamente, não exigiu que eu fosse funcionalista. Não sou funcionalista. Fiz realmente a tese como eu queria. Na verdade, eu já tinha toda a fundamentação quando fui para a Alemanha. Não houve maior problema não, a tese fluiu com suavidade. Às vezes o doutorado é muito dramático...

\section{EBJ - Teve de fazer disciplinas?}

SS - Não, obrigatoriamente lá não tem. Somente a tese.

\section{EBJ - Porque pelo currículo você ficou só um ano na Alemanha...}

CS - Na verdade, quando eu fui já tinha basicamente a tese pronta. Na Alemanha, não é obrigatório cursar disciplinas... se o candidato é muito jovem...

SS - Não há um curso de doutorado como nos Estados Unidos. Se o orientador acha que você necessita de uma complementação, de alguma disciplina que vá ajudar...

CS - O sistema é muito centralizado no orientador, cuja tendência é normalmente seguida pelos orientandos. O Luhmann foi muito suave, muito cordato, muito compreensivo. Ele não foi um professor impositivo. Solange assistiu à defesa da minha tese.

SS - Em Bielefeld, a tese é defendida somente entre os professores e os candidatos.

\footnotetext{
24 "Mudança Social e Direito".

${ }^{25}$ Participou também dessa pesquisa lone Pessoa.
} 
CS - Minhas permanências na Alemanha significaram um auto-exílio político e um autoexílio acadêmico. $\mathrm{O}$ interesse no doutorado em sociologia era porque eu trabalhava em um ambiente de sociólogos. Essa tese não tem muito a ver com o direito, é sociologia geral.

Se não basta o conhecimento, científico que seja, para informar um direito
alternativo, e o direito em geral, não lhes basta apenas o sentimento, nem mesmo
o sentimento de agradabilidade diante do que se acha que deva ser (sentimento
de justiça). O homem médio da favela, embora homem normal, homem de mente
não patológica, em virtude do conhecimento deficiente que possui, achará que
deve a mulher infiel ser espancada pelo marido - achará, em seu machismo, isso
justo, e, por isso, experimentará, diante do fato, um sentimento de uma
agradabilidade pelo menos preponderante (...).
Tem, então, esse homem, o sentimento de justiça mas, pela deficiência de seu
saber, não possui uma ideia adequada de justiça. Sua postura é uma alternativa
ao direito estatal, mas não poderá ser caracterizada como uma alternativa
jurídica, como direito alternativo, se por direito entendermos algo de
necessariamente racional (e não algo informado por conhecimento preconcebido,
inadequado à realidade, distorcido ou "torto") (s.d.b, p. 9).

EBJ - Você estava comentando que, apesar de ter feito a tese com o Luhmann, não era funcionalista. Como é que você se define teoricamente?

CS - Você diz, qual é a escola metodológica?

SS - Faça uma autodefinição sua, que tipo de sociólogo você é, você é funcionalista...

CS - Eu sou fundamentalmente teórico, pesquisador, sim. Pesquisador no sentido de técnica de pesquisa seria uma dimensão para mim menos vocacional do que a dimensão teórica propriamente dita. Mas se você entende por pesquisador aquele que procura dentro das suas modestas possibilidades alguma solução para os problemas teóricos, aí eu diria que, nesse sentido, eu seria pesquisador, mas pesquisador sobretudo de teoria básica.

O individualismo metodológico pode ser visto como uma reação à diretriz durkheimiana de que fatos sociais seriam explicados por fatos sociais, sem referência ao mental individual (s.d.a, p. 1).

\section{EBJ - Que tipo de teoria?}

SS - Ela quer saber, Cláudio, sociologicamente quais são as suas influências.

CS - Uso secundariamente uma perspectiva funcional, mas muito secundariamente, e uso cada vez mais raramente. No artigo sobre direito alternativo, usei essa perspectiva 
justamente porque queria mostrar que tudo isso é compatível. O pessoal faz uma guerra de escolas metodológicas como se isso fosse real. São perspectivas. Eu usei, por exemplo, a perspectiva dialética secundariamente, em relação àqueles macrossistemas ideológicos internacionais. A perspectiva ali é dialética, mas a minha perspectiva básica é indutivocausal. Isso tem afinidade com o positivismo lógico. Não o positivismo de identificar direito com estado, isso não tem nada a ver. Trata-se do positivismo metodológico. Você poderia dizer que, se há uma corrente em que poderia esse modesto criado seu ser colocado, seria o individualismo metodológico. No entanto, individualismo metodológico para os marxistas, salvo exceções, ainda é uma palavra feia. A tendência ainda, se bem que cada vez menor, é de uma confusão entre individualismo como ideologia e individualismo metodológico. Não tem nada a ver com isso, pois eu, como cidadão, sou socialista, membro do antigo PSB [Partido Socialista Brasileiro], da sua ala não-marxista. Vou dar a você um artigo que acabei de escrever sobre ${ }^{26} \ldots$ onde se reage àquela perspectiva durkheimiana de que os fatos sociais só são explicados pelos fatos sociais. Nesse último artigo faço, justamente, uma distinção entre propriedades emergentes fortes e fracas, no sentido de que tudo se reduz afinal, ou tudo se reduziria, a ideia, sentimento e volição, quanto ao mental e ao social [siv]. Você tem aí algo de semelhante, em termos de lógica científica. Há propriedades emergentes, mas são fracas. Em um artigo sobre individualismo metodológico no marxismo ${ }^{27}$, que cito nesse meu escrito, os autores dizem que se houvesse alguma coisa semelhante à água, então poderia haver uma teoria explicativa rigorosa do mundo social. Mas, segundo os autores, não há. O meu artigo é uma tentativa de mostrar que existiria, sim, esse elemento logicamente semelhante à água, que é o siv. Qual é o lastro teórico fundamental? Não é funcionalista, não é dialético. A tônica é indutivo-causal. Em direito alternativo, não se está fazendo, mas alguém precisa trabalhar essa vertente indutivo-causal para se tentar um maior rigor conceitual e proposicional. 0 próprio Edmundo [Lima de Arruda Júnior] reconhece, com muita verdade e humildade, que a perspectiva do direito alternativo ainda precisa de um maior rigor. Pareceu-me, portanto, que poderia ser útil fazer essa tentativa de uma teoria mais rigorosa do direito

\footnotetext{
${ }^{26}$ (s.d.a).

${ }^{27}$ Levine et al., 1987.
} 
alternativo. O direito alternativo é muito importante, pois foi o único movimento que conseguiu abalar a dogmática jurídica. Mas o movimento ainda não está muito conhecido.

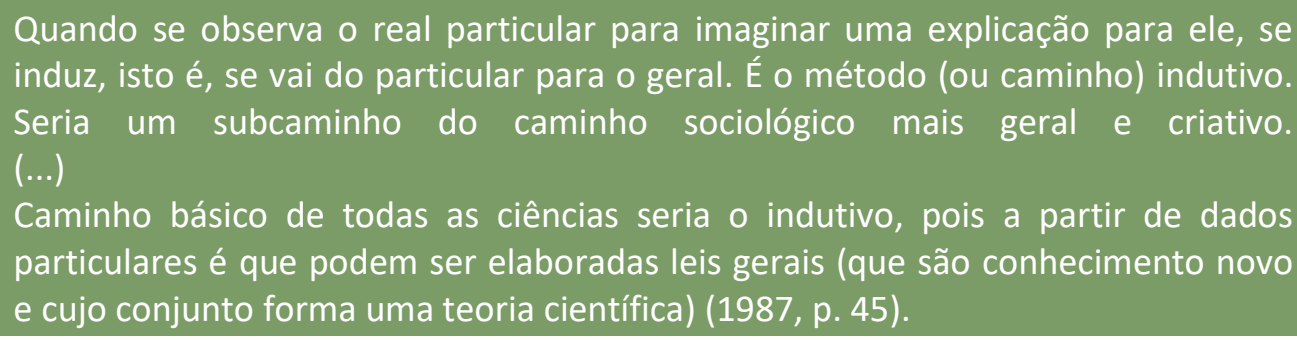

O tipo ou categoria siv é análogo, mutatis mutandis, ao tipo químico H2O: toda água é $\mathrm{H} 2 \mathrm{O}$, todo fenômeno mental ou social é siv, e se distinguem, o mental e o social, apenas pela exteriorização e pela quantidade de pólos interativos (todos do tipo siv).

Na natureza, nem a água, nem o siv, se encontram, porém, puros, mas sempre são co-operantes com outros fatores, que lhes são imbricados. A própria água da chuva, que se aproxima de um estado de pureza H20, contém os componentes do ar e poeira. Mais impuros ainda serão fenômenos mais sutis e complexos, como os mentais e os sociais (s.d., p. 5).

\section{EBJ - O Joaquim Falcão foi seu aluno? Como foi a sua aproximação com ele?}

CS - Alguma coisa ligada ao CNPq. O Joaquim manifestou desejo de vir para o Recife. Eu conversei com o pessoal de sociologia e o Joaquim veio. Quando o Joaquim veio já tinha doutorado?

SS - Ele tinha o mestrado, estava fazendo o doutorado.

CS - Ele tinha o mestrado. Eu era o coordenador nessa época?

SS - Eu acho que sim, coordenador dos estudos sócio-jurídicos.

CS - Coordenador do mestrado em sociologia?

SS - Não, não creio.

CS - Se eu não era coordenador, eu pedi para alguém da coordenação, pois Joaquim era uma pessoa de talento que vinha justamente ajudar na parte da sociologia do direito.

SS - Escreveram um livro juntos.

EBJ - Eu fiz uma entrevista com David Trubek, falando sobre este livro que, segundo ele, é fundamental. 
tornar evidente a pluralidade do conhecimento sócio-jurídico, através de suas diversas correntes fundamentais. Opção esta que relegou a segundo plano as eventuais preferências dos organizadores deste livro. Daí por que se percorre aqui um caminho que, além de alcançar autores de perspectiva empírico-nomológica, vai desde funcionalistas a dialéticos, passando por outras posições teóricas. Tal pluralidade se nos afigurou como contribuição a um processo didático aberto, sem prejuízo de que tivéssemos evitado, tanto quanto possível, textos de ideologização incompatível com a ciência atual (1980, p. xiv-xv).

CS - É um livro até que não tem muita difusão.

SS - Não tem não, pois o estudante não tem muito hábito de ler e algumas leituras são mais pesadas.

CS - Este livro deu muito trabalho. Nós tínhamos de olhar todas as traduções, escrever para cada autor pedindo autorização, pagar direito autoral...

SS - Foi meio complicado.

EBJ - Mas você nessa época teve algum contato com o movimento direito e desenvolvimento, com a vinda de David Trubek ao Brasil? Esteve com David Trubek?

CS - Não, não me lembro de ter estado com o Trubek. O texto dele está lá ${ }^{28}$, nessa época ele era uma figura bem conhecida já aqui no Brasil. O texto de Luhmann ${ }^{29}$ foi indicação de Tércio [Sampaio Ferraz Jr.], o que eu achei muito bom, pedi a uma estudante pós-graduada alemã...

EBJ - ... que depois trabalhou em uma pesquisa de vocês ${ }^{30}$...

CS - ... que fizesse a tradução ${ }^{31}$. Depois eu fiz a revisão, foi muito sutil. Quando Luhmann passou por aqui, dei o texto para ele ver. O texto do Boaventura [de Sousa Santos] foi preparado pelo próprio especialmente para o livro ${ }^{32}$. Passou por aqui um outro professor de Bielefeld, Johannes [Augel], ao qual eu mencionei que queria fazer um doutorado na Alemanha, solicitando para sondar o Luhmann a respeito. Ele sondou e o Luhmann se tornou amigo nosso, apesar de eu não ser funcionalista...

SS - Cláudio, a ideia do livro com Joaquim surgiu como?

CS - Não sei não.

\footnotetext{
28 "Para uma Teoria Social do Direito: Ensaio sobre Direito e Desenvolvimento".

29 "Direito como Generalização Congruente".

30 “Mudança Social e Mentalidade Jurídica”, financiada pelo CNPq, 1987.

${ }^{31}$ Dietlinde Hartel.

32 “Notas sobre a História Jurídico-Social de Pasárgada”.
} 
SS - A ideia era porque não existia praticamente nada.

CS - Era muito dificil se ensinar. Resolvemos fazer essa coisa prática. Agora, se a ideia foi de Joaquim ou se foi minha, eu não me lembro. Eu sei que ficou sendo dos dois.

EBJ - Você nunca foi a nenhum encontro do Research Committee on the Sociology of Law, mas você é filiado ao Research Committee...

CS - A essa altura eu nem pago mais, mas...

EBJ - O Miranda Rosa falou a mesma coisa...

CS - É um negócio pro forma, constar daquela lista de sociologia do direito e do comitê de estrangeiros da revista Sociologia del Diritto. Eles mandam sempre a revista, o que é de graça. Eu e Solange só publicamos uma vez um artigo na revista, em italiano, uma pesquisa de sociologia do direito sobre planejamento familiar ${ }^{33}$. Depois eles editaram um livro, sobre planejamento familiar em diferentes países ${ }^{34}$.

EBJ - E aquela pesquisa que o Renato Treves organizou tentando traçar o panorama da sociologia do direito?

CS - São três, mais uma editada por Vincenzo Ferrari. Eu participei de duas.

SS - Miranda Rosa fez a segunda.

CS - Depois eu fiz a terceira ${ }^{35}$ e a quarta ${ }^{36}$, esta última com Solange, você conhece a quarta. Se tivermos alguma cópia da terceira, a gente manda para você...

CS - O contato com Renato Treves foi sempre por carta, com Renato Treves e com Vincenzo Ferrari. Você tem a referência deste no seu livro. Se me chamarem de novo, você escreve, pois a essa altura você sabe muito mais do que eu. Já não sei a quanto anda a sociologia do direito no Brasil ${ }^{37}$.

EBJ - Uma pergunta provocadora: você continua achando que não faz a menor diferença usar "sociologia jurídica" ou "sociologia do direito"?

\footnotetext{
33 (1980b).

34 (1983).

35 (1976).

${ }^{36}$ (1990).

${ }^{37}$ Acrescentado por ocasião da revisão: "Fazendo a revisão desta entrevista, noto que entre esta última e agora diminuiu minha ignorância sobre a sociologia do direito no Brasil depois de 1990, pois ocorreu o fato novo do preparo de uma nova edição do Sociologia do Direito (em colaboração com Solange). Os livros de Faria e Campilongo (1991) e de Junqueira (1993) ajudaram muito".
} 
Note-se que não distinguimos "Sociologia Jurídica" de "Sociologia do Direito"e, de fato, as distinções que às vezes são apresentadas incidem em um certo verbalismo por seu caráter um tanto artificial (manifestam-se, entre outros, de modo explícito, pelo emprego indiferente das duas expressões, Carbonnier, 1972: 16; Treves, 1980: 3). Que as indagações sócio-jurídicas sejam feitas por juristas ou por sociólogos, isso não justificaria uma diferença de denominação (respectivamente "Sociologia Jurídica" e "Sociologia do Direito", como relata Tammelo, 1974: 276). Pois não é isso obviamente o relevante, mas apenas que as indagações sejam realmente científicas (1992, p. 11-12).

CS - Eu acho. Mas isso não tem problema não, a pessoa achar ou não achar.

SS - Você acha que uma coisa é mais velha do que a outra?

EBJ - Não, eu acho que sociologia do direito é sociologia e sociologia jurídica é uma teoria crítica sobre o direito, um pensamento crítico sobre o direito.

CS - Qual, a sociologia do direito?

EBJ - Sociologia jurídica seria mais uma visão crítica do direito, enquanto a sociologia do direito seria um ramo da sociologia.

SS - Interessante, eu nunca pensei nisso...

CS - Essas coisas são convencionais. Não têm importância maior classificações, denominações. É convenção. Era importante devido a uma afirmação muito grande da sociologia do direito em face aos juristas. Da mesma maneira, os juristas discriminavam a sociologia do direito no sentido de que não era direito, era sociologia...

EBJ - Eu gosto muito de citar essa passagem de vocês sobre a desconfiança mútua.

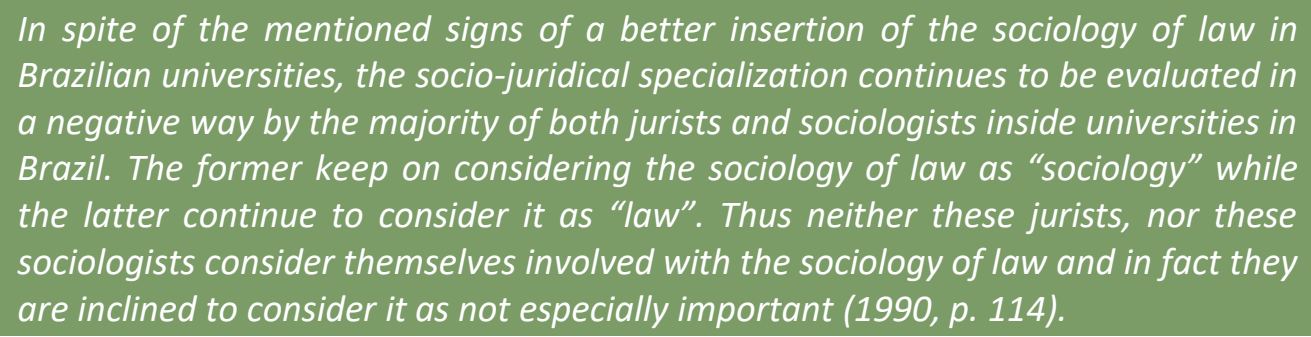

SS - Essa hostilidade...

CS - Nessa época parecia importante escolarizar isso no sentido de que não importava se a pessoa tinha a formação de jurista ou de sociólogo, o importante é que fizesse uma coisa objetiva, tanto quanto possível científica. Havia uma discriminação. No meio sociológico, na minha época e de Solange, havia bastante discriminação em relação aos juristas, no sentido de que não faziam ciência mesmo, o que, em parte, é verdade. 
SS - Inclusive, quando você ensina a disciplina sociologia mesmo, você precisa algo mais do que somente a formação jurídica. Tanto que o doutorado em sociologia do Cláudio foi em parte porque ele queria ter também o doutorado em sociologia, já que estava no mestrado em sociologia.

CS - ... convivendo com sociólogos, o tempo todo. Só voltei a ensinar na Faculdade de Direito, tardiamente, primeiro na pós-graduação e, mais tardiamente ainda, na graduação...

SS - ... após 1974.

Não é que o atual momento da Sociologia Jurídica não esteja provido, sobretudo
desde o começo do século, de juristas-sociólogos. Mas, provido quase
exclusivamente de juristas-sociólogos e não de sociólogos juristas, isto é,
constituído quase exclusivamente por lógicos das técnicas coercíveis do direito
que, sob pressão dos acontecimentos sociais em insopitável avanço sobre o
conteúdo tradicional das técnicas coercíveis, foram levados, pela necessidade de
uma solução apaziguadora, a uma interpretação nova, sociológica, relativa,
atualizada, desse conteúdo coercível. Esses juristas-sociólogos nunca deixaram de
ser essencialmente teóricos das técnicas coercíveis do jurídico, e só
interessadamente são sociólogos do direito. Quer dizer, nunca chegaram a ser
propriamente sociólogos, mas são sobretudo teóricos das técnicas do direito, e só
secundariamente, interessadamente, sociólogos. Ou seja, estranhamente
sociólogos, sociólogos em função das técnicas coercíveis do direito, a cujo serviço
puseram subalternamente a Sociologia, usada em seus dados, mas não em seus
métodos, ou técnicas, de pesquisa (1971, p. 35).

CS - ... inicialmente passei uns sete anos ensinando...

SS - É fácil: até 1963, ensinou na Faculdade de Direito. Após 1974, depois do encontro do CNPq no Rio [de Janeiro], você voltou.

CS - Eu passei fora da faculdade de direito muitos anos, de 1964 a 1974.

SS -10 anos.

CS - E primeiro voltei só para a pós-graduação. Quando fui para a graduação, não faltava muito para eu me aposentar. Havia um aspecto discriminatório, que uma pessoa mais jovem, que não tenha vivido aquela época, não percebe. Eu tenho impressão de que era internacional. Na Europa deveria haver também essa coisa...

EBJ - Mesmo nos Estados Unidos existe ainda.

SS - Hoje existe ainda? 
EBJ - Isso que eu ia perguntar: como é que vocês avaliam, trinta anos convivendo nessa área, a sociologia do direito do Brasil atualmente? Como é que está essa resistência?

CS - Eu acho que a resistência está muito menor. Já se considera bastante normal a sociologia do direito na pós-graduação como matéria obrigatória, pelo menos aqui na Universidade Federal de Pernambuco. Está havendo uma diminuição progressiva da influência kelseniana, muito progressiva. Meu feeling é que o movimento do direito alternativo contribuiu muito para isso. Além da aposentadoria de certos professores.

\section{EBJ - Uma renovação do quadro docente.}

CS - Você vê, as pessoas mais jovens, Marcelo [Neves], João Maurício [Adeodato]... Ivo Dantas foi aluno nosso no mestrado em sociologia e fez agora concurso para titular de direito constitucional.

SS - Marcelo mesmo fez sociologia do direito. João Maurício não é admirador de Luhmann?

CS - Ele é admirador de Luhmann. Ele tem essa dimensão sociológica, é bastante aberto.

SS - Eu acho que em grande parte a mudança nesses trinta anos é devida ao próprio tempo. A aposentadoria de muitos professores mais kelsenianos da dogmática jurídica e a penetração de um pensamento ainda mais novo do que o tradicional da sociologia jurídica, o pensamento do direito alternativo.

A opção do juiz pela lei inviabilizava assim qualquer opção fundamental pelos que estivessem à margem dos benefícios econômicos ou políticos maiores inviabilizava-se sua opção preferencial, portanto, pelos interesses da maioria das pessoas de qualquer macrossistema político moderno real, fosse qual fosse a ideologia desse macrossistema (1992, p. 57).

CS - O movimento alternativo muitas vezes é radical, não só no sentido de ir à raiz, mas no sentido de que, para você ter alguma coisa de efetivo que pudesse alterar o código tradicional da dogmática jurídica, era necessário ser assim. Tese, antítese, síntese. 0 movimento está com força para fazer mudanças na dogmática jurídica, que é muito poderosa, a dogmática dos juízes, dos tribunais. Para mudar essa situação tem de ser um movimento forte, não pode ser meramente teórico, encastelado nesse ponto de vista. $\mathrm{O}$ movimento do direito alternativo é importantíssimo. Do ponto de vista teórico, representa a possibilidade de abertura... é só quebrar a religiosidade marxista... Por exemplo, essa 
coisa de que o método dialético é o método de confiança... ou o método causal ...ou o funcionalismo...Depende do gosto do pesquisador, do teórico...

SS - ... da situação...

CS - ... do tema. Por exemplo, escrevendo sobre macrossistemas internacionais ideológicos, eu senti necessidade da perspectiva dialética. Mas, para definir o direito como fenômeno social de maneira mais precisa e para estabelecer uma proposição teórica rigorosa é preciso uma abordagem indutivo-causal, usada pelo positivismo lógico, pelo individualismo metodológico. A dialética, até o momento, não deu fruto no sentido de algo de menos impreciso. Nós atuamos de acordo com o tema, respeitando a vocação do pesquisador teórico, no querer ser dialético. Mas não é ser só dialético. Isso de que o que não é dialético não presta, é da direita, a chamada religiosidade marxista...

EBJ - E essa pesquisa experimental que vocês fizeram em 1979 sobre a reação da pele... Eu fiquei muito curiosa...

Os nossos sentimentos intensos, nos compostos siv, se acompanham de
alterações somáticas passíveis de muito clara constatação por nós mesmos ou por
um observador externo. Essa constatação de estados afetivo-somáticos vivos -
que se ligam ao sistema nervoso vegetativo - se faz, por assim dizer, a "olho nu",
independentemente do uso de instrumento registrador: palpitações cardíacas,
falta de ar, empalidecimento ou rubor, choro, nó na garganta, mãos úmidas, etc.
O uso de instrumental para aferição das reações afetivo-somáticas se dirige
amiúde à frequência de respiração, à pressão sanguínea - estas vias muito
acessíveis - e ao reflexo psíquico-galvânico (ou reflexo electrodermal, ou reflexo
galvânico da pele), com base aqui a verificação no decréscimo ou aumento da
resistência da pele à corrente elétrica, respectivamente em estado de excitação
emotiva ou de sossego (1974, p. 199).

CS - Nós não nos demoramos muito tempo nessa fase, e foi bom, foi providencial, porque hoje em dia está se contestando a validade desses procedimentos experimentais. 0 princípio é o mesmo princípio do detector da mentira, a diminuição da resistência da pele à passagem da corrente elétrica. As pessoas normalmente não controlam as suas reações emocionais. Uma reação que a pessoa considera injusta se registra. Excepcionalmente, as pessoas podem controlar a sua vida afetiva. Você coloca um faquir, e o aparelho não vai funcionar. O espião. É preciso que a pessoa acredite na medição. Se a pessoa não acreditar na eficácia, pode iludir a medição. Mas tirando essa ressalva... nesse último artigo eu digo 
que esse é um caminho, porque pode aferir grosso modo. Mas acho que já não vou fazer, deixo que outros façam...

SS - Inclusive nossa máquina está velha...

CS - Grosso modo é possível aferir a agradabilidade e a desagradabilidade por esse aparelho. No entanto, não é possível aferir as nuanças do afetivo. A culpa não é do teórico. A culpa é que não existe um instrumental desenvolvido capaz de realizar em ciências humanas uma aferição mais sutil. Para dar uma imagem a você, para ficar claro, quando Einstein, sem nenhuma comparação, desenvolveu a teoria da relatividade, a teoria não foi bem testada. Grande parte não era passível de teste imediato, pois dependia de um desenvolvimento tecnológico que na época não havia. A obrigação do teórico é deixar a sua teoria de maneira que seja testável, indicando a operacionalização, como se faz a tradução das proposições em operações de pesquisa. A partir daí vai depender de quem faça a pesquisa e do desenvolvimento instrumental. Uma pessoa que lida com teoria pode não entender de instrumento.

SS - Talvez seja do interesse de Eliane contar mais ou menos como foi que nós conseguimos usar essa espécie de detector de mentira.

EBJ - Vocês tinham um aparelho? Como é que vocês conseguiram esse aparelho?

CS - Pela Fundação Humbolt.

EBJ - Era um aparelho usado na Alemanha?

CS - Era usado internacionalmente. O nosso é japonês.

SS - Você pode "pegar" até um grupo de trinta pessoas. É ótimo. O próprio aparelho faz a média das emoções.

EBJ - Você tem de conectar...

SS - ... os eletrodos nos dedos, e esses eletrodos vão até a maquininha, que faz o registro.

EBJ - E nessa pesquisa vocês reuniram um grupo?

SS - Um grupo experimental. O outro era de controle.

EBJ - E submetiam o grupo a uma situação?

SS - Pronto. É isso que eu queria que Cláudio lembrasse... nós pedimos a Sebastião Vila Nova, um sociólogo da Fundação Joaquim Nabuco... 
CS - ... ele toca violão e compôs uma música... É um negócio meio complicado, porque tinha de dar o mesmo tempo para dois grupos...

SS - ... uma mesma música para duas letras, uma letra falando de justiça e outra letra de injustiça.

CS - ... para ver a reação...

SS - Agora, quem compôs as letras foi também, da Joaquim Nabuco, Alberto Cunha Lima, um poeta que Joaquim [Falcão] nos apresentou.

CS - Se você tem uma música como a de Chico Buarque de Holanda ${ }^{38}$, aquela do - em verdade não é dele, mas ele fez uma versão - Menino Jesus, se tem um impacto muito grande.

SS - Na ocasião, nós aplicamos o teste...

CS - Na ocasião era problemático ...existia judicialmente uma discussão sobre o detector de mentira. Com o instrumental, você tem o registro das repercussões orgânicas da vida afetiva da pessoa. O organismo é uma resposta menos mentirosa, mas na equação experimental você nunca elimina a letra $\mathrm{N}$, a dos fatores não controláveis. Tudo isso é relativo. O rigor metodológico é relativo. Isso não quer dizer que se deva cair na gandaia e não se preocupar com o rigor metodológico...

SS - Mas, Cláudio, nós conseguimos perceber que havia uma diferença entre o sentimento de justiça e o de injustiça ...

\section{EBJ - Vocês nunca publicaram nada sobre isso...}

CS - Não, porque Solange vetou a publicação.

SS - Justamente porque o grau de significância não era alto...

CS - Nós íamos repetir, mas...

SS - No pré-teste, o grau não era tão mais alto. Vila Nova é professor de sociologia e por isso procurou rigor metodológico: a música dele era monotônica e cada situação, com a mesma música de fundo monotônica, tendo apenas a letra diferente, não gerava um grau de significância muito alto. Com uma música do tipo Chico Buarque daria um impacto. $\mathrm{O}$ problema nosso experimental é que a música tinha de ser a mesma e ter o mesmo tempo

\footnotetext{
${ }^{38}$ Minha História (Gesubambino).
} 
para os dois grupos. A música tinha de terminar no mesmo tempo, tanto quanto possível com todas as variáveis iguais, menos ...

SS - ... a mensagem, que uma era de injustiça e outra de justiça. Eu gostei muito.

CS - Solange vetou a publicação de duas pesquisas. Qual foi mesmo a outra que você vetou?

SS - A de ensino integrado.

EBJ - A de medicina ${ }^{39}$.

SS - Teve somente publicação interna.

CS - A Solange é mais rigorosa em matéria de publicação de pesquisa do que eu. Ela é da escola americana...

SS - ... tem de estar tudo muito certinho.

CS - ... eu sou da escola de rigor em teoria. Sobre pesquisa... eu não acredito totalmente em nenhuma delas...

SS - Eu sou mais de pesquisa.

\section{EBJ - Vocês estavam se dirigindo mais ao auditório das ciências sociais ou do direito?}

CS - Eliane, a minha desgraça é que, contrariando a própria teoria que apresento, quando escrevo não penso em público e não penso em auditório. Quando escrevo, escrevo vocacionalmente, sobre um assunto de que gosto e em que, na minha opinião, poderia dar uma contribuição. Auditório... nunca me preocupei com isso. Mas, de acordo com a teoria, se não há uma relação ideativa de semelhança, não há aceitação. Sou uma pessoa marginal, remo contra as marés. Aliás, o Vila Nova em artigo tem muita sensibilidade para isso $^{40}$. Sou da época da sociologia do desenvolvimento. Até a década de oitenta, estava na moda falar nessa sociologia. Praticamente todo mundo escrevia sobre desenvolvimento. E eu escrevia sobre teoria geral, inteiramente fora, na marginalidade. Praticamente todo mundo era marxista, eu não era... mais marginalização. Era um negócio muito abstrato, muito teórico, e eu confesso que nunca me preocupei com essa questão de auditório, quem se preocupa com auditório não tem auditório...

\section{EBJ - Como vocês avaliam a contribuição de vocês para a sociologia do direito?}

\footnotetext{
39 "Ensino Integrado e Ensino Tradicional: uma avaliação empírica", experimento controlado relativo ao rendimento dos alunos do Curso de Medicina da Universidade Federal de Penambuco, realizado em 1976.

${ }^{40}$ (1944).
} 
Mas, se se pode definir o direito alternativo com relativo rigor substantivo, parece abrir-se o caminho a um conhecimento científico-social relativamente rigoroso do direito alternativo, que não se limite ao apenas descritivo, porém que venha a chegar ao próprio causal-explicativo em suas proposições. Esse conhecimento se poderia designar por Sociologia do Direito Alternativo ou, simplesmente, Direito Alternativo, com iniciais maiúsculas, e seria parte integrante da Sociologia do Direito (de onde mais diretamente se originou) (s.d.b, p. 12).

SS - A insistência. Eu acho que a contribuição foi você ter insistido, continuar escrevendo todo o tempo, na mesma linha. Para mim, foi o que mais marcou. Quando você sente que não há um público, não há o que você chama auditório para aquilo que você está fazendo, você recua, você desiste. No caso nosso, apesar de remando contra a maré tantos anos, nós continuamos, e, evidentemente, não sabíamos se a coisa iria dar certo ou não. Agora já está dando mais porque existe algo até mais avançado, que denominamos de filho da sociologia do direito, uma continuação da sociologia do direito, que é o direito alternativo, um movimento que veio bem mais forte do que a sociologia do direito tradicional e que veio exatamente porque as pessoas que no início foram, como diz Cláudio, marginalizadas, não desistiram, de jeito nenhum, continuaram, continuaram sem saber onde iam chegar. Sabiam que a dogmática somente não poderia existir, a filosofia também não. Existia campo para algo mais...

CS - Nesse sentido, era algo que tinha de ser feito e se não fosse uma pessoa que começasse, outra começaria. Quanto à teoria, é uma tentativa de responder às questões. Errando ou acertando, é preciso tentar responder. Quanto à pesquisa, um problema ligado à institucionalização, não havia pesquisa sistemática, tinha também de ser feita.

\section{an}

\section{OBRAS CITADAS DOS ENTREVISTADOS}

SOUTO, Cláudio. Da Irrealidade Jurídico-Definitiva do Direito Natural, Nova Visualização do fenômeno jusnaturalista. Recife: Imprensa Universitária, 1958 e 1960.

SOUTO, Cláudio. La Recherche Comparative comme Instrument de la Communauté de Droit des Nations. In: Problèmes Contemporains de Droit Comparé. Tokyo: Institut Japonais de Droit Comparé, 1962. 
SOUTO, Cláudio. Introdução Crítica ao Direito Internacional Privado. Recife: Imprensa Universitária, 1964.

SOUTO, Cláudio. Fundamentos da Sociologia do Direito. Recife: Imprensa da Universidade Católica de Pernambuco, 1968.

SOUTO, Cláudio. Introdução ao Direito como Ciência Social. Rio de Janeiro: Tempo Brasileiro, 1971.

SOUTO, Cláudio. Sociology of Law: A New Perspective in Brazilian Legal Education. Archiv für Rechts und Sozialphilosophie, v. 63, n. 2, 1972.

SOUTO, Cláudio. Teoria Sociológica Geral. Porto Alegre: Globo, 1974.

SOUTO, Cláudio. Brasile. In: TREVES, Renato; FERRARI, Vincenzo (ed.). L'Insegnamento sociologico del diritto. Milano: Edizioni di Comunità, 1976.

SOUTO, Cláudio. Teoria Sociológica do Direito e Prática Forense. Porto Alegre: Sergio Fabris, 1978.

SOUTO, Cláudio et al. Mudança social e mentalidade jurídica: uma pesquisa empírica. Recife: CNPq, 1979.

SOUTO, Cláudio; FALCÃO, Joaquim. Sociologia e Direito. São Paulo: Pioneira, 1980a.

SOUTO, Cláudio; SOUTO, Solange. Consultori per la pianificazione familiare in Brasile. Sociologia del Diritto, Milano, v. 7, p. 125-137, 1980b.

SOUTO, Cláudio; SOUTO, Solange. Sociologia do Direito. Rio de Janeiro: Livros Técnicos e Científicos; São Paulo, EDUSP, 1981.

SOUTO, Cláudio; SOUTO, Solange. Consultori per la pianificazione familiare in Brasile. In: SEGRE, Vera; VEDICOGNA, Nella Gridelli. Aspetti socio-giuridici del Family Planing in alcuni paesi europei et extraeuropei. Milano: Guiffrè, 1983.

SOUTO, Cláudio. O que é pensar sociologicamente. São Paulo: EPU, 1987.

SOUTO, Cláudio; SOUTO, Solange. Sociology of Law in Brazil: The Recent Years. In: FERRARI, Vincenzo (ed.). Developing Sociology of Law. Milano: Dott. A. Guiffrè, 1990.

SOUTO, Cláudio. Ciência e ética no Direito: uma alternativa de modernidade. Porto Alegre: Sergio Fabris, 1992.

SOUTO, Cláudio. Individualismo metodológico: a problemática das propriedades emergentes e da operacionalização de uma escolha determinística entre alternativas. Recife: mimeo., [s.d.a].

SOUTO, Cláudio. Direito Alternativo: em busca de sua teoria sociológica. Recife: mimeo., [s.d.b].

SOUTO, Cláudio. Beyond the Selfsufficiency of Collectivistic Approaches in Social Thought. Archiv für Rechts-und Sozialphilosophie, Stuttgart, v. 80, p. 246-251, 1994. 


\section{REFERÊNCIAS}

CARBONNIER, Jean. Flexible Droit. Paris: LGDJ, 1979.

CARBONNIER, Jean. Sociologie Juridique. Paris: Librairie Armand Colin, 1972.

FARIA, José Eduardo; CAMPILONGO, Celso. A sociologia do direito no Brasil. Porto Alegre: Sergio Fabris, 1991.

JUNQUEIRA, Eliane. A sociologia do direito no Brasil: introdução ao debate atual. Rio de Janeiro: Lumen Juris, 1993.

LEVINE et al. Marxism and Methodological Individualism. New Left Review, v. 67, 1987.

MORAES FILHO, Evaristo de. O problema de uma sociologia do direito. Rio de Janeiro: Freitas Bastos, 1950.

TAMMELO, Ilmar. La 'fase adulta' della Sociologia Giuridica. Sociologia del Diritto, 1974.

TREVES, Renato. Introduzione alla Sociologia del Diritto. Torino: Giulio Einaudi, 1980.

VILA NOVA, Sebastião. História da Sociologia e Meta-Sociologia no Brasil: um roteiro bibliográfico. Revista Interamericana de Bibliografía, v. 44, 1994.

SOUTO, Cláudio; SOUTO, Solange. HAMEL, Gary.

Entrevista com os professores Cláudio Souto e Solange

Souto. Entrevistadora: Eliane Botelho Junqueira. RBSD -

Revista Brasileira de Sociologia do Direito, v. 8, n. 3, p.

326-360, set./dez. 2021.

Recebido em: 31/05/2020

Aprovado em: 11/08/2021 